\title{
Clinical chemistry laboratory productivity: a comparison between a Canadian and a British teaching hospital
}

\author{
ARTHUR R HENDERSON* AND MARY D GARDNER $†$ \\ From the *Department of Clinical Biochemistry, University Hospital (University of Western Ontario), \\ London, Ontario, Canada, and $\dagger$ Department of Biochemistry, Royal Infirmary, Glasgow, Scotland, UK
}

SUMMARY The productivity of a clinical chemistry laboratory was measured in both a Canadian and a British tertiary care teaching hospital using 1977 data and the 1976 edition of the Canadian Schedule of Unit Values. Although productivity, measured as units produced per person or per paid hour, was lower in the British than in the Canadian teaching hospital-due to the British dayrelease system of staff-education - the output per actual worked hour was similar. We conclude, from this small study, that productivity in the laboratory services of the British National Health Service is not likely to be different from laboratory productivity elsewhere.

As part of a study of clinical chemistry utilisation in teaching hospitals in Canada and Britain, ${ }^{1}$ based on data collected in 1977, we have examined the productivity of one Canadian and one British clinical chemistry laboratory.

For a number of years Britain has earned an international reputation for poor industrial productivity, and this, together with the stigma of 'socialised medicine' has suggested a poorer level of productivity within the National Health Service itself. ${ }^{2}$ We have attempted to measure productivity by a standard method to test this belief. International comparisons of productivity are notoriously difficult to make, on both practical and theoretical grounds, but the workload recording method for clinical laboratory procedures ${ }^{3}$ takes account of many of the practical problems that bedevil productivity measurements in industry, such as the heterogeneity of input and output, the quality and intensity of labour outputs, the capital investment in plant and equipment, and many other factors. The workload recording method is accepted in both Canada ${ }^{3}$ and the United States (as the College of American Pathologists' System) as an adequate, albeit imperfect method of measuring laboratory productivity, although it is not yet in general use in Britain.

Our original study involved three Canadian and three British teaching hospitals, ${ }^{1}$ but in the present study we have used only one hospital in each country

Accepted for publication 3 September 1980 to exclude the effect of laboratory overcrowding on productivity. ${ }^{4}$ Both laboratories in this study were built and occupied in the 1970s specifically for clinical chemistry work, and there were no limitations of space during 1977 .

\section{Methods and results}

The 1977 workload figures (total units and the numbers of patient tests) were collected from University Hospital, London, Ontario, Canada and from Glasgow Royal Infirmary, Glasgow, Scotland. These hospitals are teaching hospitals affiliated with the medical schools of the Universities of Western Ontario and Glasgow, respectively. Both hospitals belong to the tertiary-care category as defined by Mechanic. ${ }^{5}$ The patient statistics giving rise to the workloads were also obtained. These data are shown in Table 1. Unit calculations were carried out in accordance with the procedures detailed in the Canadian Schedule of Unit Values, ${ }^{3}$ using the 1976 edition.

About $70-80 \%$ of tests were analysed by 'automated' methods, and these tests, together with the analysers used, are listed in Table 2 . The number of staff employed to produce and report analytical results in each hospital are listed together with their 'total paid hours' (which includes overtime) and 'actual worked hours'. This latter category is obtained by reducing the total paid hours by the amount of statutory holidays, annual leave, sick 
Table 1 Patient and workload data for 1977

\begin{tabular}{|c|c|c|}
\hline & $\begin{array}{l}\text { University } \\
\text { Hospital, } \\
\text { Canada }\end{array}$ & $\begin{array}{l}\text { Glasgow } \\
\text { Royal } \\
\text { Infirmary }\end{array}$ \\
\hline $\begin{array}{l}\text { Total beds } \\
\text { (acute)* } \\
\text { Total bed days (inpatient) } \\
\text { Outpatient visits } \\
\text { Emergency/casualty visits } \dagger \\
\text { Total patient tests } \\
\text { Total clinical chemistry units } \\
\text { (including quality control and } \\
\text { calibration work) }\end{array}$ & $\begin{array}{c}391 \\
(391)^{*} \\
119662 \\
72193 \\
21014 \\
913801 \\
3530092\end{array}$ & $\begin{array}{rll} & 2 & 197 \\
& (1 & 557)^{*} \\
807 & 471 \\
726 & 569 \\
726 & 93 & 210 \\
1 & 124 & 519 \\
7 & 550 & 489\end{array}$ \\
\hline
\end{tabular}

*Number of acute-care beds in parentheses.

†Emergency department (Canada) is designated as casualty department in Britain.

Table 2 Major serum analytes and analysers*

\begin{tabular}{|c|c|c|}
\hline & $\begin{array}{l}\text { University Hospital, } \\
\text { Canada }\end{array}$ & $\begin{array}{l}\text { Glasgow Royal } \\
\text { Infirmary }\end{array}$ \\
\hline Sodium, potassium & $\begin{array}{l}13 \mathrm{ch} \\
\text { IL Flame }\end{array}$ & $\begin{array}{l}7 \mathrm{ch} \\
\text { IL Flame }\end{array}$ \\
\hline Chloride & $\begin{array}{l}13 \mathrm{ch} \\
\text { Coulometer }\end{array}$ & $\begin{array}{l}7 \mathrm{ch} \\
\text { Coulometer }\end{array}$ \\
\hline Bicarbonate & $13 \mathrm{ch}$ & $7 \mathrm{ch}$ \\
\hline Urea, creatinine & $13 \mathrm{ch}$ & $7 \mathrm{ch}$ \\
\hline Glucose & $\begin{array}{l}13 \mathrm{ch} \\
\text { AA II }\end{array}$ & Beckman \\
\hline Calcium & $\begin{array}{l}13 \mathrm{ch} \\
\text { AAS }\end{array}$ & AA II \\
\hline Phosphorus & $13 \mathrm{ch}$ & AA II \\
\hline Total protein & $13 \mathrm{ch}$ & $\begin{array}{l}7 \mathrm{ch} \\
\text { AA II }\end{array}$ \\
\hline Albumin & $13 \mathrm{ch}$ & AA II \\
\hline Urate & $13 \mathrm{ch}$ & AA II \\
\hline Total bilirubin & $13 \mathrm{ch}$ & AA II \\
\hline Cholesterol & CA & AA II \\
\hline Triglyceride & CA & AA II \\
\hline Transaminases & LKB & LKB \\
\hline Creatine kinase & LKB & LKB \\
\hline $\begin{array}{l}\text { Lactate } \\
\text { dehydrogenase }\end{array}$ & LKB & LKB \\
\hline $\begin{array}{l}\gamma \text {-glutamyl } \\
\text { transferase }\end{array}$ & $\mathbf{C A}$ & LKB \\
\hline Alkaline phosphatase & CA & LKB \\
\hline
\end{tabular}

* The alternative analyser is listed when substantial use is made of the alternative system.

Abbreviations for analysers

$13 \mathrm{ch}, 7 \mathrm{ch}=$ number of automated channels in an integrated analyser system, eg, SMA or equivalent; IL Flame = Flame Photometer (Instrumentation Laboratories Inc, Lexington, MA 02173); Coulometer $=$ coulometric titration technique; AA II = Autoanalyzer II continuous-flow system (Technicon Instruments Corporation, Tarrytown, NY 10591); Beckman = Glucose Analyzer (Beckman Instruments, Inc, Fullerton, CA 92634); AAS = atomic absorption spectrometer; titrator = Fluorescent Titrator (Oxford Laboratories Inc Foster City, CA 94404); CA = Gemsaec centrifugal analyser (ElectroNucleonics, Inc, Fairfield, NH 07006); LKB $=8600$ reaction rate analyser and Ultrolab System 2086 Mark II kinetic analyser (LKBProdukter AB, Bromma, Sweden).

time, and, in the case of Glasgow Royal Infirmary, by day-release time. Payroll records were used to obtain these data, which are given in Tables 3 and 4 .

Both laboratories used computer reporting systems in 1977. At University Hospital, the system then ran (and continues to do so) 24 hours each day.
Table 3 Staffing in the Department of Clinical Biochemistry at University Hospital required for analyses and reporting of patient care work

\begin{tabular}{lccr}
\hline Category & $\begin{array}{l}\text { Number } \\
\text { (full-time } \\
\text { equivalent) }\end{array}$ & $\begin{array}{l}\text { Total } \\
\text { paid } \\
\text { hours }\end{array}$ & $\begin{array}{l}\text { Actual } \\
\text { worked } \\
\text { hours }\end{array}$ \\
\hline Professional staff & 1 & 2100 & 1960 \\
Supervisory technologists* & $5 \cdot 1$ & 9993 & 8551 \\
Technologists* & $26 \cdot 4$ & 51499 & 46109 \\
Clerk/typist* & 2 & 3913 & 3527 \\
Glass washer $\dagger$ & 1 & 2080 & 1944 \\
Totals & $35 \cdot 5$ & 69585 & 62091 \\
\hline
\end{tabular}

*37.5 h/week.

$\dagger 40 \mathrm{~h} /$ week.

Table 4 Staffing in the Department of Biochemistry at Glasgow Royal Infirmary required for analyses and reporting of patient care work

\begin{tabular}{llcr}
\hline Category & $\begin{array}{l}\text { Number } \\
\text { (full-time } \\
\text { equivalent) }\end{array}$ & $\begin{array}{l}\text { Total } \\
\text { paid } \\
\text { hours }\end{array}$ & $\begin{array}{l}\text { Actual } \\
\text { worked } \\
\text { hours }\end{array}$ \\
\hline $\begin{array}{l}\text { Professional staff } \\
\begin{array}{l}\text { Supervisory medical laboratory } \\
\text { scientific officers* }\end{array}\end{array}$ & $7 \cdot 5$ & 13650 & 13624 \\
$\begin{array}{l}\text { Medical laboratory scientific } \\
\text { officers* }\end{array}$ & 64 & 14277 & 11947 \\
$\begin{array}{l}\text { Clerk/typist } \dagger \\
\begin{array}{l}\text { Glass washer } \ddagger \\
\text { Totals }\end{array}\end{array}$ & $6 \cdot 5$ & 129824 & 100194 \\
\hline
\end{tabular}

*38 h/week.

$\dagger 37 \mathrm{~h} /$ week.

$\$ 40 \mathrm{~h} /$ week.

All results were entered in real time, and complete cumulative reports were issued three times each week with interim reporting carried out four times each day. The use of the computer allowed a reduction of three full-time equivalents of staff. Staffing levels in Table 3 are for staffing after completion of the computer installation.

At Glasgow Royal Infirmary the computer system produced (1977) cumulative reports only from the seven-channel analyser (see Table 2), operated only during the working day, and had not then created any reduction in the staffing of the department.

A number of estimates of productivity are shown in Table 5 derived from the data in Tables 1,3 , and 4. Table 6 contains information on the professional staffing of each department.

\section{Discussion}

The data given in Table 1 indicate that, per acutecare bed, University Hospital carries out more clinical chemistry tests than Glasgow Royal Infirmary by a factor of about threefold. We have shown, in fact, that for the common tests, such as creatinine 
Table 5 Estimates of productivity

\begin{tabular}{lll}
\hline & $\begin{array}{l}\text { University Hospital, } \\
\text { Canada }\end{array}$ & $\begin{array}{l}\text { Glasgow Royal } \\
\text { Infirmary }\end{array}$ \\
\hline $\begin{array}{l}\text { Units produced per person } \\
\text { Units produced per paid } \\
\text { hour }\end{array}$ & $\begin{array}{l}99439 \\
50.73\end{array}$ & $\begin{array}{l}87390 \\
43.29\end{array}$ \\
$\begin{array}{l}\text { Units produced per actual } \\
\text { worked hour }\end{array}$ & 56.85 & 53.33 \\
\hline
\end{tabular}

Table 6 Professional staff in post in 1977

\begin{tabular}{llc}
\hline & $\begin{array}{l}\text { University } \\
\text { Hospital, } \\
\text { Canada }\end{array}$ & $\begin{array}{l}\text { Glasgow } \\
\text { Royal } \\
\text { Infirmary }\end{array}$ \\
\hline $\begin{array}{llc}\text { Physician } \\
\text { Clinical chemist (non-physician) }\end{array}$ & 1 & $2+(3)$ \\
$\begin{array}{c}\text { Senior echelon } \\
\text { Others, ie, training and early } \\
\text { post-training grades }\end{array}$ & 1 & $\begin{array}{c}5+(2) \\
15+(1)\end{array}$ \\
\begin{tabular}{l} 
Medical residents/registrars \\
\hline
\end{tabular} & 1 & $5 \cdot 5$ \\
\hline
\end{tabular}

The figures in parentheses indicate the number of university, as opposed to National Health Service, professional staff.

and potassium, the factor between the Canadian and British hospitals is actually about eightfold and that for glucose the factor is as large as 20 -fold more tests per patient day. ${ }^{1}$

It will be noted (Table 1) that, although similar patient test numbers were produced by both laboratories, the unit values are twofold different. An examination of Table 2 partially explains this difference. A single-channel analyser is eightfold less efficient than a 12-(or greater) channel analyser per analyte. ${ }^{3}$ Thus, the 31706 total bilirubin analyses carried out on patients at Glasgow Royal Infirmary on a single channel analyser generates 126824 units whereas the same work done at University Hospital on a multichannel analyser would have generated only 15853 units. When the unit 'cost' of calibration and quality control are additionally taken into account it can be appreciated why the amount of labour (that is, the number of units) can be, in aggregate, as much as twofold different.

The data given in Tables 3 to 5 require some explanation. By 'professional staff' we mean a clinical chemist who has, at least, a BSc degree (and who also often has a PhD degree), several years of training in clinical chemistry, and a professional qualification in the discipline of clinical chemistry awarded by a professional association such as the Royal College of Pathologists (Britain) or the Canadian Society of Clinical Chemistry. A clinical chemist may also possess a medical qualification.

The ratio of actual worked hours to total paid hours (Table 3-technologist; Table 4-medical laboratory scientific officer (MLSO)) is 0.90 at University Hospital and $\mathbf{0 . 7 7}$ at Glasgow Royal Infirmary. This disparity is due to the educational system employed in Britain for medical laboratory scientific officer education. A day-release arrangement (on full pay) allows junior staff to attend technical college one day each week for the professional education necessary to pass the examinations leading to the award of a Higher National Certificate in Medical Laboratory Sciences. Possession of this certificate leads to state registration. A British MLSO is not qualified until he/she becomes state registered. This usually takes four years of day-release study. In Canada, the technologist attends a community college for two years of full-time education to obtain the registered technologist (RT) diploma, after which employment can be obtained in a hospital laboratory. Thus, in Britain professional education is more highly subsidised by the employer (the National Health Service) than is the case in Canada. Otherwise hours of work per week are very similar in each country (see footnotes to Tables 3 and 4).

The ratio of supervisory technical staff to junior staff is $1: 5 \cdot 2$ at University Hospital and 1:10 at Glasgow Royal Infirmary. When the number of professional staff at Glasgow Royal Infirmary is taken into account (Table 6) this disparity disappears. In constructing Table 4 , we have allowed for those members of the professional staff whose major commitment has been in method development or research so that the comparison between hospitals is strictly on the grounds of the provision of a patient care service, although we agree that, to an extent, such a distinction is both artificial and misleading.

Our estimates of productivity are shown in Table 5. The workload recording method unit is based on '. . . the average technical, clerical and aide time needed to accomplish each procedure', 3 and is defined as being equivalent to 1 minute of technical, clerical, and aide time. The unit values '. . . measure the time for specimen processing and testing; clerical work, including logging and recording of results; supportive activities such as solution preparation and glassware washing, preparation and reading of blanks'. All quality control procedures, standards, repeats, and duplicates are considered as additional procedures as defined above. Thus a number of measures of productivity, that is, total output per input, can be made. These are shown in Table 5. The measure 'unit per person' is used by the Ontario Ministry of Health as a rough guideline for the staffing of independent departments. They have assumed that each person (ie, full-time equivalent) should 'generate' about 100000 units per annum. Obviously the day-release system operated in Britain is not allowed for in such a measure but when the data are adjusted accordingly, a similar ratio is obtained. For the same reason the 'units per total paid hours' is misleading in the case of Glasgow 
Royal Infirmary, and correction of this measure gives a value of about 50 units. Finally, the most useful measure of all-'units per actual worked hours'-is very similar in the two hospitals. We can conclude therefore that the overall efficiency of both laboratories is comparable.

It can be argued that the laboratory of a large acute-care hospital will be more efficient than the laboratory of a small hospital because, in the former, the batch sizes will be larger and the available staff can work more efficiently with large specimen:quality control and calibration sample ratios. We have chosen a large British hospital, which is likely to be more efficient than smaller British hospitals, and compared its productivity with a small Canadian hospital, which, in turn, is likely to be less efficient than larger Canadian hospitals. In fact, data produced by the Ontario Hospital Association ${ }^{6}$ indicate that University Hospital had the highest productivity (measured as units per paid hour) of the 20 Ontario teaching hospitals in 1977 and that the total cost of the diagnostic services was in the lowest quartile among these hospitals. Thus, University Hospital's productivity compares favourably with teaching hospitals in Ontario up to 1000 beds in size. This finding is not entirely unexpected because the hospital opened only in 1972, and its efficiency, compared with that of older hospitals, should be higher.

The clinical chemistry laboratory in Glasgow Royal Infirmary was opened in 1976 and it, too, must be expected to show maximal efficiency and productivity among British hospitals. Therefore, we believe that our comparison is very likely valid because we have chosen two laboratories with modern facilities working under favourable conditions of space, equipment, and staffing.

One other factor needs to be taken into account. At University Hospital two technologists work a 'back-shift' (1500-2300) and one technologist works a 'night-shift' (2300-0700) to provide a limited routine service and an emergency (stat or priority) service, ${ }^{7}$ whereas at Glasgow Royal Infirmary requests (designated as emergencies) received outside the normal working day (0900-1700 on weekdays and 0900-1300 on Saturdays) are dealt with by a 'callback' system. These different modes of working are included in Tables 3 and 4, but it is obvious that the shift-working at University Hospital must reduce overall efficiency. These different methods of providing a service are typical of each country's normal mode of laboratory operation, and this also lends credibility to our findings.

As clinical chemistry laboratories are among the busiest services in hospitals we believe that this small survey indicates that a laboratory in the British National Health Service is every bit as efficient as laboratories elsewhere in the world. The claims $^{2}$ of low productivity within the National Health Service may be true during periods of industrial action but the example we have chosen demonstrates that in happier times this is not so.

Efficient throughput of test requests in a laboratory is of no consequence if the test itself is of no value in the management of the patient. The low cost of most clinical chemistry tests ${ }^{8}{ }^{9}$ appears to have misled physicians into thinking that the clinical chemistry service is cheap. It is not. In the Ontario teaching hospitals the cost of the clinical chemistry service is as much as $5 \%$ of the annual operating budget of the hospital. We should ensure, by a continuing dialogue between laboratory and clinical services, that the extent of relevant testing is increased. This is where hospital laboratories with adequate professional staffing can make extremely useful contributions.

The number of professional staff at Glasgow Royal Infirmary (Table 6) is sufficient to maintain an effective dialogue with the clinical services. For example, the medically qualified clinical chemist on the duty team at Glasgow Royal Infirmary is responsible for ward liaison. This duty includes suggestions for further investigations on patients whose reports have already been issued, monitoring requests and results in acute-care situations, and generally facilitating ward-laboratory communication. This function is rarely possible in the Ontario environment in a regular, on-going fashion because of the paucity of professional staff. The data in Table 6 are echoed in the national figures for Britain ${ }^{10}$ and Ontario. ${ }^{11}$ Thus there are 28 and 14 clinical chemists per million of population in the British Health Service and the Ontario hospital system, respectively. These data suggest that wardlaboratory dialogues may be less frequent in the Ontario hospital environment than in Britain. Certainly we were impressed during our survey ${ }^{1}$ by the inverse relation between the number of clinical chemists and the workload. We agree that other factors are involved but our experience, and that of others, ${ }^{12}$ suggest that talking to clinicians about their requests will often reduce the number of tests required. There is evidence that this can be effective when weekly out-of-hours emergency test requests were reduced from an average of 66 to two. ${ }^{13}$

We have purposely digressed from the main aim of this work - to compare productivity in two countries-because we are firmly convinced that, while this type of comparison is valuable, input: output statements ignore the relevance of much of the 'output', and we have tried to stress that a reduction in productivity may be associated with a better service to patients. 


\section{References}

${ }^{1}$ Henderson AR, Gardner MD, Griffiths PD, Owen JA, Porter CJ, Tonks DB. Clinical chemistry in Britain and Canada. New Eng J Med 1980;303:113-4.

${ }^{2}$ Lister J. By the London post. New Eng J Med 1980;302: 280-2.

${ }^{3}$ Canadian schedule of unit values for clinical laboratory procedures. Ottawa: Hospitals Section, Health Division, Statistics Canada, 1976:19-25.

4 Newell JE. Reorganization of laboratories. In Laboratory management. Boston: Little, Brown \& Company, 1972: 147-50.

${ }^{5}$ Mechanic D. Medical sociology. 2nd ed. New York: Free Press, 1978:350-75.

${ }^{6}$ Ontario Hospital Association Consolidation: Public Teaching Hospitals Quarterly Hospital Information System-1 January to 31 December 1977. Ottawa: Canadian Hospital Association, Statistics Canada, 1978:28-32.

${ }^{7}$ Henderson AR. The priority test request form. $J$ Clin Pathol 1979;32:97-9.

${ }^{8}$ Fineberg HV. Clinical chemistries: the high cost of lowcost diagnostic tests. In: Altman SH, Blendon R, eds.
Medical technology: the culprit behind health care costs.' Washington: US Department of Health, Education and Welfare [DHEW Publications No. (PHS 79-3216)], US Government Printing Office, 1979:144-65.

${ }^{9}$ Fineberg HV, Hiatt $\mathrm{HH}$. Evaluation of medical practices: the case of technology assessment. $N$ Eng J Med 1979; 301 : 1086-91.

10 Anonymous. Number of members in IFCC-affiliated national societies of clinical chemistry. IFCC Newsletter $1979 ; 21: 8$.

${ }^{11}$ Ansonymous. Canadian Society of Clinical Chemistry Membership Roster as of 30 September 1978. Ottawa: Canadian Society of Clinical Chemistry, 1978:1-6.

12 Carter PM, Davison AJ, Wickings HI, Zilva JF. Quality and quantity in chemical pathology. Lancet 1974;ii 1555-7.

${ }^{13}$ Manley G. The incidence of biochemical emergencies. Br Med J 1980;280:330.

Requests for reprints to: AR Henderson, Department of Clinical Biochemistry, University Hospital, PO Box 5339, Postal Station A, London, Ontario, Canada N6A 5A5. 